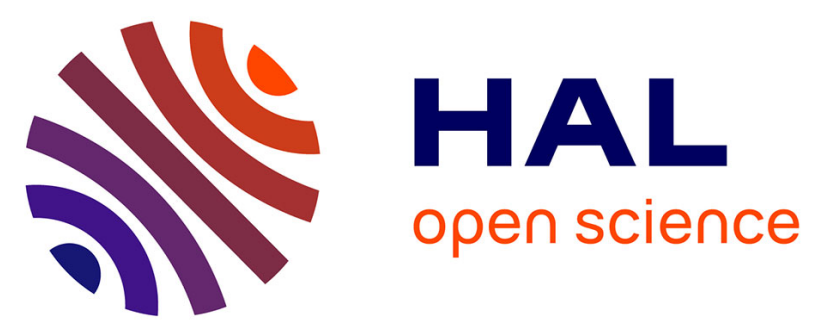

\title{
Accretion-controlled forearc deformation pulses recorded by high-pressure paleo-accretionary wedges: the example of the Hellenic subduction zone
}

Armel Menant, Onno Oncken, Johannes Glodny, Samuel Angiboust, Laurent Jolivet, Romain Augier, Eloïse Bessière, Taras Gerya

\section{To cite this version:}

Armel Menant, Onno Oncken, Johannes Glodny, Samuel Angiboust, Laurent Jolivet, et al.. Accretioncontrolled forearc deformation pulses recorded by high-pressure paleo-accretionary wedges: the example of the Hellenic subduction zone. EGU General Assembly 2021, Apr 2021, Vienne, Austria. pp.EGU21-5897, 10.5194/egusphere-egu21-5897 . hal-03508303

\section{HAL Id: hal-03508303 \\ https://hal.science/hal-03508303}

Submitted on 3 Feb 2022

HAL is a multi-disciplinary open access archive for the deposit and dissemination of scientific research documents, whether they are published or not. The documents may come from teaching and research institutions in France or abroad, or from public or private research centers.
L'archive ouverte pluridisciplinaire HAL, est destinée au dépôt et à la diffusion de documents scientifiques de niveau recherche, publiés ou non, émanant des établissements d'enseignement et de recherche français ou étrangers, des laboratoires publics ou privés. 


\title{
EGU21-5897
}

https://doi.org/10.5194/egusphere-egu21-5897

EGU General Assembly 2021

(c) Author(s) 2022. This work is distributed under

the Creative Commons Attribution 4.0 License.

\section{Accretion-controlled forearc deformation pulses recorded by high- pressure paleo-accretionary wedges: the example of the Hellenic subduction zone}

\author{
Armel Menant ${ }^{1}$, Onno Oncken ${ }^{1}$, Johannes Glodny ${ }^{1}$, Samuel Angiboust ${ }^{2}$, Laurent Jolivet ${ }^{3}$, Romain \\ Augier $^{4}$, Eloïse Bessière ${ }^{3}$, and Taras Gerya ${ }^{5}$ \\ ${ }^{1}$ GFZ Helmholtz Centre Potsdam, German Research Centre for Geosciences, Potsdam, Germany (armel.menant@gfz- \\ potsdam.de) \\ ${ }^{2}$ CNRS, Institut de physique du globe de Paris, Université de Paris, Paris, France \\ ${ }^{3}$ Sorbonne Université, UMR 7193 CNRS-UPMC, Institut des Sciences de la Terre de Paris, Paris, France \\ ${ }^{4}$ Université d'Orléans, ISTO, UMR 7327, Orléans, France \\ ${ }^{5}$ Institute of Geophysics, Swiss Federal Institute of Technology (ETH), Zürich, Switzerland
}

Subduction margins are the loci of a wide range of deformation processes occurring at different timescales along the plate interface and in the overriding forearc crust. Whereas long-term deformation is usually considered as stable over Myr-long periods, this vision is challenged by an increasing number of observations suggesting a long-term pulsing evolution of active margins. To appraise this emerging view of a highly dynamic subduction system and identify the driving mechanisms, detailed studies on high pressure-low temperature (HP-LT) exhumed accretionary complexes are crucial as they open a window on the deformation history affecting the whole forearc region.

In this study, we combine structural and petrological observations, Raman spectroscopy on carbonaceous material, Rb/Sr multi-mineral geochronology and thermo-mechanical numerical models to unravel with an unprecedented resolution the tectono-metamorphic evolution of the Late-Cenozoic HP-LT nappe stack cropping out in western Crete (Hellenic subduction zone). A consistent decrease of peak temperatures and deformation ages toward the base of the nappe pile allows us to identify a minimum of three basal accretion episodes between ca. $24 \mathrm{Ma}$ and ca. $15 \mathrm{Ma}$. On the basis of structural evidences and pressure-temperature-time-strain predictions from numerical modeling, we argue that each of these mass-flux events triggered a pulse in the strain rate, sometimes associated with a switch of the stress regime (i.e., compressional/extensional). Such accretion-controlled transient deformation episodes last at most ca. 1-2 Myr and may explain the poly-phased structural records of exhumed rocks without involving changes in far-field stress conditions. This long-term background tectonic signal controlled by deep accretionary processes plays a part in active deformations monitored at subduction margins, though it may remain blind to most of geodetic methods because of superimposed shorter-timescale transients, such as seismic-cycle-related events. 
